\title{
THE STOCK MARKET AND EARLY ANTITRUST ENFORCEMENT*
}

\author{
GEORGE BITTLINGMA YER \\ University of California, Davis
}

$\mathrm{T}$

HE turn-of-the-century struggle over trusts and corporations gave birth to industrial economics. In fact, that era's hotly debated questionspredation, merger, vertical restrictions, federal incorporation, and patent licensing - have an eerie familiarity. But one topic has never been followed up: did trust-busting hurt the stock market, as many critics claimed at the time?

At one level, the answer is clear. Filing suits against large corporations and threatening to break them up and force changes in the way they do business is bound to lower their value. The stock prices of actual defendants, likely targets, and firms whose business plans or hopes of merger are spoiled should all drop. The idea also has a stellar endorsement: Irving Fisher chalked up the boom market of the 1920s to restrained antitrust. ${ }^{1}$ But today the notion seems bold, bizarre, and obviously false. To many economists, antitrust is a sometimes misguided but basically sound and minor part of government economic policy.

The statistical work in this article links federal antitrust filings and ten stock-price indexes over the period 1904-14, from the revival of antitrust under Teddy Roosevelt to the passage of the Clayton Act and the Federal Trade Commission (FTC) Act. My strategy is to exploit the instability of enforcement in the intervening years, an instability that seems to have been generated by the volatile politics of the trust question.

* I am grateful for comments at the University of California (Davis, Los Angeles, and Santa Barbara), Washington University (St. Louis), Vanderbilt University, the Federal Reserve Board, the Federal Trade Commission, George Mason Law School, Cornell University, Ohio State University, the San Francisco Federal Reserve Bank, and the National Bureau of Economic Research Macro History Workshop. Special thanks go to Brad Barber, Lee Benham, John Matsusaka, David Rocke, Bob Smiley, Ted Snyder, Michael Waldman, Richard Wydick, and an anonymous referee. Harold Mulherin provided the daily Dow data, and Barry Stiefel collected the firm-level stock prices. The Olin Foundation supported work on this article through a grant to the Center for the Study of the Economy and the State.

${ }^{1}$ Irving Fisher, The Stock Market Crash-and After, 101, 106, 110 (1930). Also see the remarks of Wesley Clair Mitchell, Business Cycles (1913).

[Journal of Law \& Economics, vol. XXXVI (April 1993)]

(C) 1993 by The University of Chicago. All rights reserved. 0022-2186/93/3601-0001\$01.50 


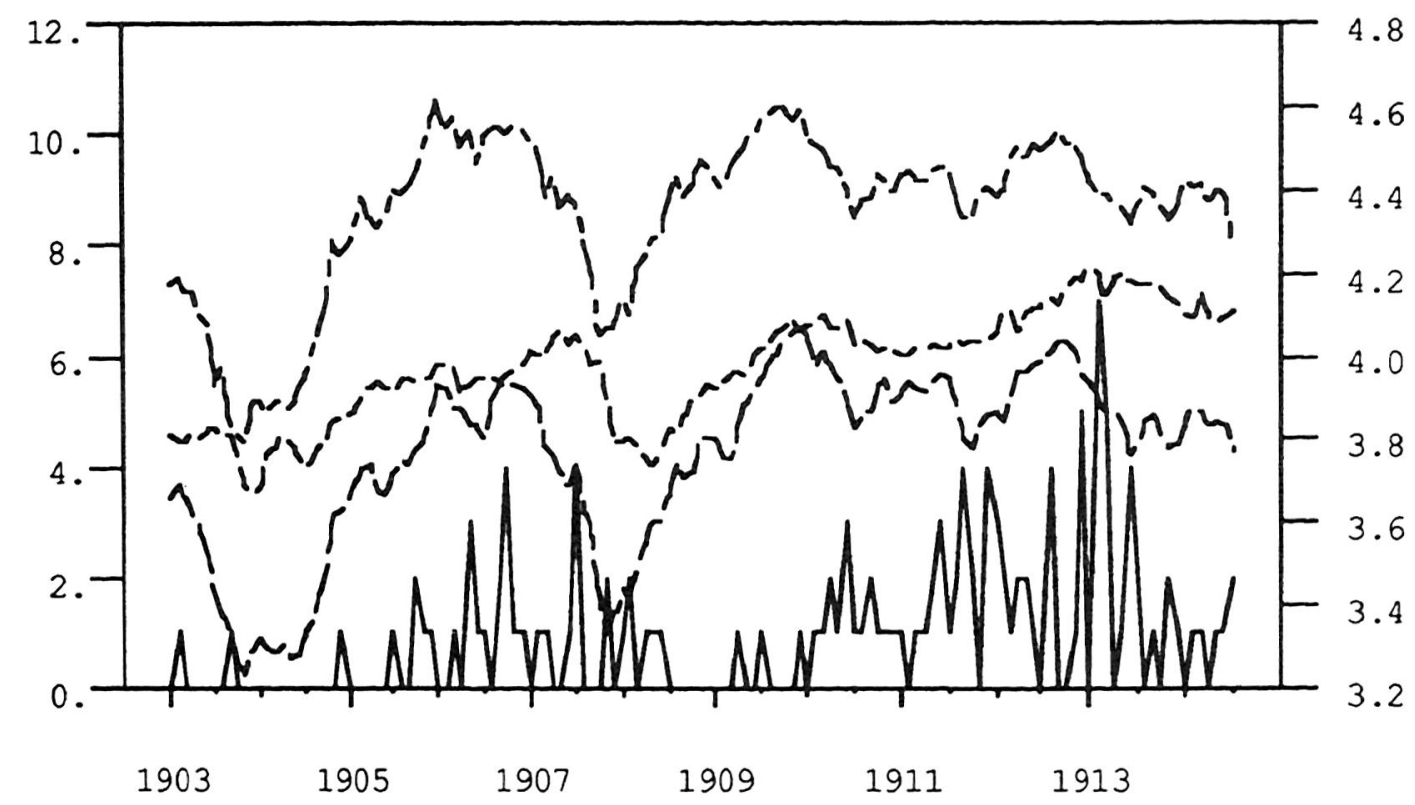

FIGURE 1.-The Dow Industrials, industrial production, the Cowles industrial index, and the number of federal antitrust case filings (from top to bottom), 1903-14.

Figure 1 presents some of the relevant data: the Dow Jones Industrial Index, industrial production, and the Cowles industrial index - all in natural logs-as well as the number of cases filed. The spikes in enforcement in 1906 and 1907 and again in 1910, 1911, and 1912 seem to have been matched by declines in stock prices. Regression estimates in fact show that an extra case per month followed cumulative drops of major stock indexes of 1-3 percent. The timing makes sense since news of investigations and pending filings leaked out, often months in advance. These results are largely unchanged when I use current and future industrial production to control for factors not reflected in case filings. They are also stable across two subperiods, one covering Theodore Roosevelt's celebrated trust-busting and the other covering enforcement under William Howard Taft and Woodrow Wilson. Even industry indexes that included no defendants experienced large declines.

This article is organized as follows. Section I takes up the politics, enforcement, and court interpretation of antitrust for 1890-1914. Section II covers institutional and economic aspects of antitrust enforcement, discusses why I use antitrust case filings as my explanatory variable, and summarizes some leading theories of how antitrust might affect stock prices. Section III presents statistical results on the link between the Dow and case filings over short intervals, and Section IV presents estimates based on various monthly Cowles and Dow stock indexes and monthly case filings, as well as industrial production. Finally, Section V examines 
collateral issues: did the stock price of an actual defendant also drop months ahead of the filing? Was that drop larger than for the aggregate indexes? Concluding comments follow.

\section{Politics, Enforcement, and Interpretation of the Sherman Act}

\section{A. The $1890 \mathrm{~s}$}

The Sherman Antitrust Act was passed in July 1890 on the heels of agitation against the trusts. ${ }^{2}$ Its prohibition of combinations, contracts, and conspiracies in restraint of trade and monopolization was based on common law, and, in fact, some observers thought it simply codified the common law. ${ }^{3}$ Early enforcement was sporadic, ${ }^{4}$ and the Supreme Court's interpretation puzzling. In E. C. Knight, it said that merger was per se legal and sanctioned the New Jersey holding company law of 1889 ; but in two railroad cases and Addyston, the court then ruled that cartels were per se illegal and threw out common-law precedent. ${ }^{5}$ This awkward posture caused many firms to merge between 1898 and $1902 .{ }^{6}$ The Addyston defendants merged in 1898 , even before their final, unsuccessful appeal was over. ${ }^{7}$

${ }^{2}$ See Hans B. Thorelli, The Federal Antitrust Policy: Origination of an American Tradition, chs. 2 and 3 (1955); William Letwin, Law and Economic Policy in America: The Evolution of the Sherman Antitrust Act, ch. 3 (1965); and Lester G. Telser, A Theory of Efficient Cooperation and Competition, ch. 2 (1987).

${ }^{3}$ If true, Senator Sherman's law may have been the "fig leaf" for the protectionist McKinley tariff, which Sherman also pushed and lauded as the most important law passed by the 51st Congress. Thomas DiLorenzo, The Origins of Antitrust: An Interest Group Perspective, 5 Int'l Rev. L. \& Econ. 73 (1985); and Thomas Hazlett, The Legislative History of the Sherman Act Re-examined, 30 Econ. Inq. 263 (1992).

${ }^{4}$ Cases were filed against a coal cartel, railroads, lumber dealers, the Sugar Trust, the Distilling and Cattle Feed Trust, and unions over the period 1890-95.

${ }^{5}$ U.S. v. E.C. Knight 156 U.S. 1 (1895); U.S. v. Trans-Missouri 166 U.S. 312 (1897); U.S. v. Joint Traffic 171 U.S. 505 (1898); U.S. v. Addyston Pipe, 85 Fed. 271 (1898), mod'd and aff'd, 175 U.S. 211 (1899). Mark Grady, Toward a Positive Economic Theory of Antitrust, 30 Econ. Inq. 225 (1992), views the rejection of common-law precedent as an error.

${ }^{6}$ Why did firms, in the absence of antitrust, prefer unstable cartels to stable merger? The answer may lie in the cost of merger. See George Bittlingmayer, Did Antitrust Policy Cause the Great Merger Wave? 28 J. Law \& Econ. 77 (1985), for arguments and evidence. Scott E. Masten, James W. Meehan, \& Edward A. Snyder, The Costs of Organization, 7 J. L. Econ. \& Org. 1 (1991), find that mistaken vertical integration increases organizational costs about 70 percent. In contrast, John J. Binder, The Sherman Antitrust Act and the Railroad Cartels, 31 J. Law \& Econ. 443 (1988), finds little or no effect of the Trans-Missouri and Joint Traffic decisions on railroad stocks, which is consistent with the view that the substitute forms, such as merger, leasing, secret agreements and "communities of interest," were relatively low-cost alternatives to cartels and pools.

${ }^{7}$ George Bittlingmayer, Price-fixing and the Addyston Pipe Case, 5 Res. L. \& Econ. 57 (1983). 
Piling irony on irony, William McKinley filed only three antitrust suits. His attorneys general pointed to E. C. Knight at every turn to explain why they stood helpless against the wave of mergers taking place on their watch. ${ }^{8}$ When Theodore Roosevelt became president in September 1901, no case had been filed in over two years, but there was no lack of potential antitrust defendants. ${ }^{9}$ Congress was also active on the trust question. ${ }^{10}$ The original "trusts" had disappeared, but the policy question had turned into the "trust and corporation problem."

\section{B. Roosevelt's First Term}

The Republicans put Roosevelt on their 1900 ticket to get him out of New York, where he was governor. Wall Street regarded him as a loose cannon, in part because of his position on antitrust. Stocks fell sharply when McKinley was shot in September 1901, again when he died, and then rebounded partly. ${ }^{11}$ I mention the rebound to give an accurate picture of the net movement. Table 1 shows the daily changes in the Dow for these and other selected events. In fact, the Dow remained at the lower postassassination level the rest of the month and took a long dive over the next two years as Roosevelt worked the trust question. The Dow reached its mid-1901 value only in late 1904, following a one-year suspension of antitrust suits. Roosevelt's trust-busting began in earnest with the March 1902 filing against the Northern Securities railroad merger and the suit in May against the Chicago meat packers. ${ }^{12}$ The defendants in both cases were disliked, especially in the Midwest.

New Jersey granted the Northern Securities charter on November 12,

${ }^{8}$ Letwin, supra note 2, at 137-42.

${ }^{9}$ State and private cases were filed, and reports of cartels appeared in the press. Thorelli, supra note 2, at 260-65. Binder, supra note 6, at 448-449, mentions contemporary accounts of railroad agreements; and The Iron Age, December 13, 1900, at 13, reported the formation of a pool for cast-iron soil pipe. Other reports of cartels appear in Lewis Haney, Business Organization and Combination 154 (1914); and Henry R. Seager and Charles A. Gulick, Trust and Corporation Problems 90-92 (1929).

${ }^{10}$ It created the Industrial Commission "to consider and amend legislation" and approved appropriations for an investigation of trusts in 1898. The House passed a proposed constitutional amendment on trusts as well as a drastic amendment of the Sherman Act in mid-1900. Thorelli, supra note 2, at 355 and 510; and Eliot Jones, The Trust Problem in the United States 325-26 (1928). The amendment would have denied interstate transportation to firms that hindered competition by increasing or decreasing prices. It passed 274-1.

"For Wall Street reaction, see Henry F. Pringle, Theodore Roosevelt: A Biography 237-38, 244-46 (1931); and William Henry Harbaugh, Power and Responsibility: The Life and Times of Theodore Roosevelt 153 (1961). Letwin, supra note 2, at 196; and Thorelli, supra note 2 , at 417 , are also relevant.

12 U.S. v. Northern Securities, 193 U.S. 197 (1904); and U.S. v. Armour \& Co., 142 Fed. 808 (1906). 
TABLE 1

Selected Events Linked with the Trust Issue and The Daily Dow Return

\begin{tabular}{|c|c|c|}
\hline Date & Event & $\begin{array}{c}\text { Change } \\
\text { in Dow (in \%) }\end{array}$ \\
\hline September 6,1901 & President McKinley shot & -4.53 \\
\hline September 14,1901 & McKinley dies, Roosevelt becomes president & -4.36 \\
\hline September 16, 1901 & Rebound from McKinley's death & 4.02 \\
\hline February 2, 1902 & Northern Securities case announced & -1.31 \\
\hline April 9, 1903 & Northern Securities Court of Appeals decision & -2.49 \\
\hline March 14, 1904 & Northern Securities Supreme Court decision & 2.61 \\
\hline March 16, 1904 & $\begin{array}{l}\text { U.S. attorney general: "No running amuck on } \\
\text { trusts" }\end{array}$ & 1.10 \\
\hline May 4, 1906 & Theodore Roosevelt's message on trusts & 3.00 \\
\hline June 22, 1906 & Announcement of Standard Oil investigation & -1.89 \\
\hline March 7, 1907 & Standard Oil decision & -1.53 \\
\hline March 14, 1907 & Roosevelt's ICC directive & -8.65 \\
\hline March 15, 1907 & Rebound from March 14 & 6.48 \\
\hline July 10, 1907 & American Tobacco filed & -1.15 \\
\hline July 30, 1907 & DuPont filed & -1.25 \\
\hline August 3, 1907 & Standard fined for violating Elkins Act & -1.37 \\
\hline October 22,1907 & Government rejects offer to settle Standard suit & -2.84 \\
\hline November 26, 1907 & Attorney general on settlement of Standard suit & 2.61 \\
\hline December 2, 1907 & Roosevelt's message on trusts & 2.96 \\
\hline March 25, 1908 & Roosevelt endorses Hepburn Bill & 1.21 \\
\hline July 7, 1908 & Standard's Elkins Act fine overturned & .65 \\
\hline December 17, 1908 & President-elect Taft's speech on trust policy & -2.23 \\
\hline April 30, 1909 & Attorney general's speech on antitrust & .03 \\
\hline May 15,1911 & Standard Oil Supreme Court decision & 2.29 \\
\hline May 29,1911 & American Tobacco court decision & -.99 \\
\hline September 23,1911 & Attorney general's speech on antitrust & -.93 \\
\hline October 7,1911 & Taft's speech on antitrust & -.01 \\
\hline October 27,1911 & U.S. Steel filed & -3.05 \\
\hline April 30, 1912 & International Harvester filed & -.18 \\
\hline \multicolumn{2}{|c|}{ Mean of all days, January 1897-July 1914} & .011 \\
\hline \multicolumn{2}{|c|}{ Standard deviation of all days, January 1897-July 1914} & .997 \\
\hline \multicolumn{2}{|c|}{ Mean of 28 event days above } & -.421 \\
\hline \multicolumn{2}{|c|}{ Standard deviation of 28 event days above } & 3.043 \\
\hline
\end{tabular}

1901. The Interstate Commerce Commission (ICC) ordered hearings on the merger in December, Minnesota filed an antitrust suit to enjoin the consolidation in February, and the U.S. attorney general issued a statement on February 19, 1902, contending that the merger violated the Sherman Act. ${ }^{13}$ The filing itself took place on March 10, nineteen days after the attorney general's announcement.

${ }^{13}$ B. H. Meyer, A History of the Northern Securities Case 258 (1 Bulletin of the University of Wisconsin, Economics and Political Science Series, No. 3, 1906) (reprinted by Da Capo Press, New York, 1972). 
Roosevelt's deliberate goal was to overturn E. C. Knight. The Supreme Court did in fact vote 5-4 in March 1904 to declare the merger illegal but issued four separate opinions. The good news was that only four justices of the majority were prepared to prohibit all mergers of competitorsmerger was not a per se violation. The bad news was that holding companies no longer provided shelter from the Sherman Act. Interestingly, Roosevelt's attorney general played down the favorable ruling. There would be no "running amuck" on corporate control. ${ }^{14}$ Still, this muddled opinion revived the Sherman Act and laid the basis for future attacks on merged firms and the holding company. ${ }^{15}$

The Beef-Trust case followed an uproar caused by increases in the price of beef in early 1902. ${ }^{16}$ The Expediting Act of 1903 and the founding of the Bureau of Corporations and the Antitrust Division were also major antitrust initiatives. ${ }^{17}$ When the Dow dropped 13.7 percent in July 1903, some Wall Street critics blamed Roosevelt's push for publicity as a solution to the corporation problem. ${ }^{18}$ Interestingly, no new cases were filed from September 1903 to December 1904, after the election, and the new Bureau of Corporations was largely idle.

\section{Roosevelt's Second Term}

After a three-year pause, Roosevelt resumed his trust-busting. The Chicago meat packers (July 1905), the Terminal Railroad Association

${ }^{14}$ N.Y. Times, March 16, 1904. Quoted in Pringle, supra note 11, at 352. Pringle surmises that a conciliatory pose was struck to keep campaign contributions flowing on the eve of the 1904 election.

${ }^{15}$ Robert Bork. The Antitrust Paradox: A Policy at War with Itself 30 (1978), comments on "Justice Harlan's ineptitude in doctrinal disputation." Letwin, supra note 2, at 182: "The coming to age of the Sherman Act was marked by the Northern Securities case." Ernest Gellhorn, Antitrust Law and Economics 304 (1981), calls it "the starting point for a discussion of merger law.'

${ }^{16}$ A series of articles in the New York Herald on March 31, April 1, and April 6, 1902, apparently stimulated the case. Thorelli, supra note 2 , at 427 . Meatpacking had been under attack since refrigerated rail transport allowed the geographic concentration of the industry in Chicago. See Gary D. Libecap, The Rise of the Chicago Packers and the Origins of Meat Inspection and Antitrust, 30 Econ. Inq. 242 (1992). The only other cases filed during Roosevelt's first term involved an alleged conspiracy of salt producers in the western states and a combination of wholesale grocers in Florida.

${ }^{17}$ Jeremiah Whipple Jenks \& Walter E. Clark, The Trust Problem 230 and app. F-3 (1929); and Letwin, supra note 2, at 216.

${ }^{18}$ Wall St. J., August 12, 1903, at 1, criticized the New York Sun for linking Roosevelt's policies and the "Rich Man's Panic" of 1903. "To connect President Roosevelt and the disturbed conditions in Wall Street as cause and effect is preposterous. . . The causes of the upheaval in Wall Street are well understood[:] . . . over-speculation and overcapitalization." But after a decade of trust-busting, it took a different view. See text at note 48 infra. 
(December 1905), Otis Elevator (March 1906), Virginia-Carolina Chemical (May 1906), Standard Oil (November 1906), American Tobacco, DuPont (both July 1907), and Union Pacific (November 1907), as well as a string of smaller firms, local associations, and cartels were targets. Several of the suits sought divestiture as the remedy for alleged predation.

The case against Standard, filed November 15, 1906, deserves special attention. Disgruntled oil interests had urged prosecution of Standard since the Sherman Act was passed. ${ }^{19}$ After Ida Tarbell's articles on Standard appeared in the magazine McClure's in 1902, Roosevelt began criticizing Standard publicly. ${ }^{20}$ In the year and a half before the federal filing, at least fourteen states had filed suits of their own. ${ }^{21}$ A May 1906 Bureau of Corporations report concluded that Standard used unfair methods, including railroad rebates, to gain advantage over its competitors. A string of newspaper articles called for prosecution, and the government announced a preliminary investigation on June $22,1906 .{ }^{22}$

Matters went from bad to worse after the filing. A January 1907 ICC report concluded that Standard practiced local price cutting. Standard's jurisdictional challenge to the St. Louis circuit court was defeated in March, a second unfavorable report was issued by the Bureau of Corporations in May, and Standard lost state suits in May and June. It was fined $\$ 29$ million on August 3 for violating the Elkins Act, ${ }^{23}$ and the Bureau of Corporations issued a new report the same day castigating Standard for "unreasonable" profits. ${ }^{24}$ The possibility of criminal charges, raised in August and September, was another bad turn of events. Standard offered to settle, but the attorney general declined on October 22 and informed Standard's directors on October 25 that the president was constitutionally obligated to proceed. ${ }^{25} \mathrm{Up}$ to that point, the Dow had dropped 25.6 percent from August 1, before the possibility of criminal

${ }^{19}$ Bruce Bringhurst, Antitrust and the Oil Monopoly: The Standard Oil Cases, 1890-1911, at ch. 5 (1979). Telser, supra note 2 , at 36-41, finds that the margin between refined and crude oil decreased with the formation and growth of the Standard Trust in January 1882.

${ }^{20}$ Bringhurst, supra note 19, at 69.

${ }^{21}$ Ralph W. Hidy and Muriel E. Hidy, Pioneering in Big Business, 1882-1991, table 52, at $683(1955)$.

${ }^{22}$ Malcolm R. Burns, The Competitive Effects of Trust-busting: A Portfolio Analysis, 85 J. Pol. Econ. 717, 731 (1977), finds that Standard's market-corrected stock price fell 6.5 percent in November 1906. Its price, however, fell 22 percent over the previous year against a flat market. The November drop probably reflected only part of the total effects.

23 "The heavy fine inflicted upon the Standard Oil Co. at Chicago was the one absorbing topic of conversation throughout the day, and other news was practically neglected." Wall St. J., August 6, 1907, at 4, col. 1.

${ }^{24}$ Wall St. J., August 5, 1907, at 6, col. 1.

${ }^{25}$ Bringhurst, supra note 19, at 135-36. 
charges had been raised. It had dropped 38.1 percent below its January 2 value.

Roosevelt took other actions in 1907 that might have unsettled financial markets. ${ }^{26}$ When the market dropped 8.3 percent on March 14, E. H. Harriman told reporters, "I would hate to tell you to whom I think you ought to go for an explanation of all this." ${ }^{27}$ Roosevelt's March 15 directive to the ICC to investigate the railroads may have been the cause. ${ }^{28}$ The American Tobacco and DuPont filings were also seen as major assaults, ${ }^{29}$ as was the proposed policy of putting antitrust violators in receivership. $^{30}$

The charge that Roosevelt caused the panic was widespread. In fact, "appeals for modification or temporary suspension or compromise poured in upon him from many sources, including persons who had hitherto upheld his course." ${ }^{31}$ James Day, chancellor of Syracuse University, crystallized this sentiment in his book, The Raid on Prosperity. ${ }^{32}$ Even the New York Times, which had supported the president's trust policy, feared that prosperity would be ruined by antitrust prosecutions. ${ }^{33}$ Roosevelt responded in August that it was not he but, rather, "certain malefactors of great wealth" who had deliberately provoked the panic "in order to discredit the policy of the government." In January 1908 he blamed the recession on "the speculative folly and the flagrant dishonesty of a few men of great wealth." 34

${ }^{26}$ In fact, John D. Rockefeller predicted in January that Roosevelt's attacks on business would cause hard times. George E. Mowry, The Era of Theodore Roosevelt, 1900-12, at :16 (1958).

${ }^{27}$ Quoted in Harbaugh, supra note 11, at 310.

28 "It was President Roosevelt and nobody else who precipitated the panic of March 14." Wall St. J., July 2, 1907, at 6, col. 4.

${ }^{29}$ Wall St. J., July 10, 1907, at 1, and July 11, 1907, at 6.

${ }^{30}$ N.Y. Times, July 9, 1907, at 2; July 12, at 11 ; July 13 , at 6 ; July 14 , pt. 2 , at 5 . One article said Wall Street was hardened to financial shocks after two years of antitrust suits. N.Y. Times, July 11, 1907, at 2.

${ }^{31}$ Joseph Bucklin Bishop, Theodore Roosevelt and His Time: Shown in His Own Letters 35 (1920). Roosevelt spent a good deal of his time replying to these entreaties. To New York banker Jacob Schiff on March 28: "It is difficult for me to understand why there should be this belief in Wall Street that I am a wild-eyed revolutionist." Id. at 41 .

32 James Day, The Raid on Prosperity (1907). See also Adolph Edwards, The Roosevelt Panic of 1907 (1907); and J. W. Weed, A War of Words between President Roosevelt and J. Pierpont Morgan concerning Railroads, Tariff and Trust Questions and the Panic of 1907 (1907).

${ }^{33}$ N.Y. Times, August 11, 1907, pt. 2, at 6, col. 1.

${ }^{34}$ Quoted in Mowry, supra note 26, at 220-21. Roosevelt's biographer, Harbaugh, supra note 11, at 311, reports that "the President was subjected to heavy pressure from business to let up," especially after [Standard Oil] was fined \$29 million in August for violating the Elkins Act. Harbaugh argues, however, that "the financial disturbances were caused by an international overextension of credit rather than by Roosevelt's pronouncements." 
In response to a request by $\mathrm{J}$. P. Morgan's associates for postponement of the case to calm the financial waters, Attorney General Charles J. Bonaparte said on November 26 that "we can assent to no action which involves the admission that the course of the Administration in enforcing the Anti-Trust laws was, or is now, responsible for the existing financial complications." This sounded like "no" but left the door open to a colorable excuse. The federal prosecutor did in fact grant a postponement until January 6 on December 2, arguing that it was "good policy." Bonaparte agreed and termed the suspension "very judicious.",35

Compromise had been an option throughout $1907 .{ }^{36}$ But by late fall matters became earnest. Roosevelt's December 1907 message to Congress recommended amendment of the Sherman Act "to forbid only the kind of combination which does harm to the general public." ${ }^{37}$ Standard's offer to settle-rejected earlier-was entertained from April to July 1908. The brakes were also applied to antitrust generally. Only eight cases were filed in 1908, all in the first half of the year, compared to eleven in 1907, and none of the eight targets was a major industrial firm. Roosevelt directed his attorney general not to sue International Harvester, and he approved U.S. Steel's merger with Tennessee Coal and Iron in the midst of the 1907 Panic. ${ }^{38}$ Roosevelt's willingness to modify the Sherman Act was made concrete in early 1908. The National Civic Federation in consultation with the president and the commissioner of corporations drew up a statute, which was known as the Hepburn Bill, in order to permit "reasonable" restraints of trade. It would have allowed the Bureau of Corporations to approve industry agreements. ${ }^{39}$

\section{Taft's Assault}

As president-elect, William Howard Taft had signaled a tough stance, ${ }^{40}$ but he filed only three cases during his first year in office. Only one case involved a "trust," American Sugar. But a barrage of filings followed in

${ }^{35}$ Bringhurst, supra note 19, at 137-38.

36 The N.Y. Times, January 25, 1907 at 1, col. 5, speculated that Roosevelt would attack only "bad" trusts, apparently in response to private appeals to soften his attacks.

${ }^{37}$ Quoted from Martin J. Sklar, The Corporate Reconstruction of American Capitalism, 1890-1916, at 216 (1988).

38 See Pringle, supra note 11, at 445, on the first episode; and Harbaugh, supra note 11, at 314 , on the second. The steel merger served as the basis for the 1911 U.S. Steel suit.

39 Arthur M. Johnson, Antitrust Policy in Transition, 1908: Ideal and Reality, 47 Miss. Valley Hist. Rev. 415 (1961); and Sklar, supra note 37, at 203-85, provide the background on the Hepburn Bill. It was introduced into the House on March 23, and Roosevelt endorsed it on March 25, 1908, but it was never passed.

${ }^{40}$ Paolo E. Coletta, The Presidency of William Howard Taft 154 (1973). See Table 1 for the Dow's reaction to his speech, delivered December 16, 1908. 
1910 and 1911 under his attorney general, George Wickersham. By the end of his term in 1913, Taft had filed seventy-two cases in four years, compared to only forty-one filed by Roosevelt in seven.

The policy was deliberate. ${ }^{41}$ Taft outlined his views in October 1911: "We must get back to competition: If it is impossible, then let us go to socialism, for there is no way between." According to the Wall Street Journal, "[H]e said that he recognized the harm to business that such prosecuting would bring, but declared that prosecutions must go on." Taft was quoted: "A reform of any evil is bound to produce for a time not disaster, we may hope, but difficult situations that may make business halt." 42 In another 1911 speech he said, "Every trust of any size that violates the statute will, before the end of this administration in 1913, be brought into court to meet and acquiesce in a degree of disintegration by which competition between its parts shall be restored and preserved." ${ }^{43}$ Taft directed his December 1911 message to Congress at one issue: control of the trusts.

When the National Civic Federation surveyed opinion on the trust question, ${ }^{44}$ many business leaders blamed antitrust for poor business conditions. ${ }^{45}$ Wesley Clair Mitchell, who typically stressed monetary factors in business cycles, saw a connection between antitrust, the economy, and stock prices in 1911.46 John Bates Clark and John Maurice Clark wrote, "[B]reaking up too many corporations at once would be highly disturbing in the realm of business." 47 The Wall Street Journal wondered

${ }^{41}$ Wickersham predicted that one hundred corporations would be sued and corporate officials sent to jail. Henry F. Pringle, Life of and Times of William Howard Taft 669 (1939); also N.Y. Times, September 23, 1911, at 2, col. 2; N.Y. Times, September 24, 1911, at 1, col. 7.

42 Wall St. J., October 7, 1911, at 1, col. 4. See also Mowry, supra note 26, at 286.

${ }^{43}$ Pringle, supra note 41 , at 669.

${ }^{44}$ National Civic Federation, The Trust Problem: Replies of 16,000 Representative Americans to a Questionnaire (1912). Some economists, notably Frank Taussig, thought the trusts might have to be regulated. Id. at 361-62. John Bates Clark \& John Maurice Clark, The Control of the Trusts 135 (1912), argued that federal price control would put "a damper on inventive genius."

${ }^{45}$ National Civic Federation, supra note 44. To the question, "In your judgment what caused or causes the present disturbed business conditions?" the president of Lackawana Steel answered: "lack of certainty as to what is or is not legal under the Sherman Law"; the president of Lane Cotton Mills: "prosecution, or rather persecution, of large business organizations"; the president of Oliver Iron Mining: "uncertainty as to the exact meaning of the Sherman Law; the apparent unfavorable attitude of government officials towards large corporations" (id. at 7-11).

${ }^{46}$ Mitchell, supra note 1, at 85 . Quoted and discussed at text at note 64 infra.

${ }^{47}$ Clark \& Clark, supra note 44 , at 3. 
why Taft, who had received a strong vote of confidence from business in the 1908 election, should try to destroy the prosperity of the country. ${ }^{48}$ But Taft held firm: "We are going to enforce that law or die in the attempt." 49 He did develop doubts. In January 1912, he asked his attorney general whether it was necessary to file both criminal and civil charges against United Shoe Machinery. ${ }^{50}$ After hearing rumors that criminal charges would be filed in the steel suit, he told his attorney general in February that "I should like to be consulted before action of that sort is taken." 51

The case against U.S. Steel, filed October 27, 1911, came after House hearings earlier that year. Roosevelt testified in August and defended his approval of the merger with Tennessee Coal and Iron during the 1907 panic. Still, he was named in the suit, along with a "Who's Who" of American capitalists (Morgan, Rockefeller, Carnegie, Gary, and Frick, for example). ${ }^{52}$ International Harvester, filed April 30, 1912, was turned into a second jab at Roosevelt, who was accused of tolerating the "farm machinery trust." 53

The Supreme Court decisions in Standard Oil and American Tobacco were also major antitrust developments. The cases, decided May 15 and May 29, 1911, both showed that case outcomes were ambiguous. The government "won" these cases, but the divestitures were criticized. ${ }^{54}$ In

48 Wall St. J., October 11, 1911 at 1, col. 3. Coletta, supra note 40, at 163: "It was also said that business would no longer support Taft and the Republican party would instead turn to Judson Harmon in 1912 as the "most constructive' . . of the Democratic hopefuls."

${ }^{49}$ Letter dated November 5, 1911, quoted in Donald F. Anderson, William Howard Taft: A Conservative's Conception of the Presidency 81 (1968).

${ }^{50}$ Pringle, supra note 41, at 669-70.

${ }^{51}$ Quoted in Anderson, supra note 49, at 81.

52 Taft's special prosecutor had prepared the suit in secrecy "to prevent possible speculation in steel securities." Pringle, supra note 41, at 671 . Still, the case was not a surprise. Two weeks earlier, the Wall St. J., October 10, 1911, at 1, col. 3, ran a story about "a group of brokers gathered around the ticker . . . discussing United States Steel, the Sherman law and the probability of the Steel Trust being dissolved."

${ }^{53}$ Coletta, supra note 40 , at 161 . Roosevelt's approach to trusts is typically viewed as a major factor leading to his "Bull Moose," Progressive candidacy, which made the 1912 presidential election a three-way race between Roosevelt, Taft, and the Democrat Wilson. Oddly enough, the "trust-busting" Roosevelt was the probusiness candidate. He differentiated between "good" and "bad" trusts, an approach both of his opponents rejected.

${ }^{54}$ Seager \& Gulick, supra note 9, at 123 and 177-78, quoting Louis Brandeis in December 1911: "the decision of the U.S. Circuit approving the plan submitted by the American Tobacco Company is in effect a nullification not only of the Sherman Law, but of the decision of the Supreme Court of the United States." Burns, supra note 22, provides statistical support for the view that the dissolution decrees were a pleasant surprise for stockholders. 
addition, the "rule of reason" developed by the court was probably on the mild side of possible interpretations of the Sherman Act. ${ }^{55}$ In fact, Congress ultimately reversed the Supreme Court when it passed the Federal Trade Commission and Clayton Acts. ${ }^{56}$ The Dow actually increased 2.3 percent following the Standard Oil decision and dropped slightly after the Tobacco decision.

\section{E. Wilson's First Two Years}

Woodrow Wilson continued Taft's policy of aggressive filings. ${ }^{57}$ The pressure for antitrust reform also mounted. Wilson's policies were heavily influenced by Louis Brandeis, a bitter foe of big business and a skilled propagandist. Still, Wilson seemed to fear the possible link between antitrust and the economy. A tough trust policy had been one of Wilson's campaign promises, but he struck a conciliatory pose: "The antagonism between business and government is over," he told Congress in January $1914 .{ }^{58}$ His advisers had in fact urged him to postpone new antitrust legislation because of the recession. ${ }^{59}$ This first phase of U.S. antitrust ended in the fall of 1914, when Congress passed and Wilson signed the Clayton and FTC Acts. ${ }^{60}$

\section{F. Summary}

The broad terms of the Sherman Act can support strict or lax antitrust, depending on enforcement and interpretation. By 1901 its main achieve-

${ }_{55}$ But one Supreme Court Justice would probably have preferred to let the defendants off: Oliver Wendell Holmes. He thought the Sherman Act was "a humbug based on economic ignorance and incompetence" (quoted in Letwin, supra note 2, at 53), and he dissented vigorously in Northern Securities.

${ }^{56}$ See Seager \& Gulick, supra note 9, at ch. 20; Letwin, supra note 2, at 265-70; and Jenks \& Clark, supra note 17, at 231-34, on the trail that leads from the 1911 decisions to the 1914 legislation. Other decisions also played a role: Minnesota v. Northern Securities 194 U.S. 48 (1904), held that a state cannot sue for an injunction under the Sherman Act. Henry v. A.B. Dick Co., 244 U.S. 1 (1912), held that a patentee selling a patented article may restrict its use to unpatented supplies sold by the patentee. The Clayton Act allowed states to seek injunctions, and it prohibited tying.

${ }^{57}$ Over the next two years, suits were filed against American Telephone and Telegraph, American Can, United Shoe, Burroughs Adding Machine, Eastman Kodak, and Corn Products, for example.

${ }^{58}$ Quoted in Thomas K. McCraw, Prophets of Regulation: Charles Francis Adams, Louis D. Brandeis, James M. Landis, Alfred E. Kahn 118 (1984).

${ }^{59}$ August Heckscher, Woodrow Wilson 324 (1991).

60 "Everyone understood that if Wilson were regarded as antibusiness during a period of economic downturn, then the Democratic party would suffer in the off-year elections of 1914. This was one reason why Congress balked at voting adequate appropriations for the new FTC." McCraw, supra note 58, at 126. 
ment was to drive many firms away from loose cooperative arrangements and toward merger and the holding company. Roosevelt revived the law and undertook sporadic, politically motivated attacks on many of the newly formed or expanded corporations. In the face of charges that his policies hurt business confidence, he was willing in 1904 and again in late 1907 to early 1908 to cut back enforcement and even propose a new law that would be friendlier to business. Taft's policy, in contrast, was stubborn, perhaps even inept, in the face of similar criticism. Filings probably capture only a fraction of short-run policy swings by the president and Congress, especially in 1907. The Supreme Court, while also important, often bowed to political pressure and sought compromise. Antitrust played an important role in several presidencies, it was intimately wrapped up with the rise of the modern corporation and the "corporation problem," and its evolution often seems to have been governed by chance or political factors. ${ }^{61}$

\section{Case Filings, Antitrust, and Stock Prices}

\section{A. Federal Case Filings}

All told, the Department of Justice filed 127 antitrust cases from January 1904 through July 1914, but they were only the tip of the antitrust iceberg. Clearly, Congress, the president, and the courts did a lot more than file cases. In addition, states and private parties filed suits. ${ }^{62}$ Still, federal filings have some virtues. They are relatively homogeneous, and their filing dates are easily established. Filing a suit is clearly an enforcement action, and in the end only enforcement matters. Other federal activities - hearings and votes in Congress, presidential pronouncements, the establishment of new agencies, and court decisions-are important, but the construction of useful measures would be tricky. Each federal case does imply more litigation than meets the eye. In some cases, the Justice Department moved against corporations already under attack by other government agencies or in state or private suits. Standard Oil is the

\footnotetext{
${ }^{61}$ I have ignored the merits of the cases. See John S. McGee, Predatory Pricing Cutting: The Standard Oil (N.J.) Case, 1 J. Law \& Econ. 137 (1958); Kenneth G. Elzinga, Predatory Pricing: The Case of the Gunpowder Trust, 13 J. Law \& Econ. 223 (1970); David Reiffen \& Andrew N. Kleit, Terminal Railroad Revisited: Foreclosure of an Essential Facility or Simple Horizontal Monopoly? 33 J. Law \& Econ. 409 (1990).

${ }^{62}$ Michael A. Duggan, Antitrust and the Supreme Court, 1929-1971 (1972), lists seventyone antitrust cases decided by the Supreme Court after the 1895 E. C. Knight decision and before passage of the Clayton and FTC Acts in 1914. The government filed only twentythree of these, less than one-third.
} 
leading example. In other cases federal filings provoked private or state piggyback suits. ${ }^{63}$

Federal filings are special in other ways. First, the government exercises prosecutorial discretion. The hundred-year history of antitrust is replete with examples. Second, case filings reflect a political reality to which the Supreme Court often defers. It is naive to think that the high court simply interprets the law. Third, the government can throw lawyers at a case that private plaintiffs would pass up. Winning a case in the end may not matter to a president who expects to be out of office in less than four or eight years. Finally, certain types of economically important filings, like the large-firm deconcentration case, are exclusively federal actions.

From a statistical point of view, case filings are a count or Poisson-like variable with a fairly low mean (roughly a case per month), which implies that the value for a given month or even several months depends on underlying factors as well as random influences. For that reason and because all filings are not the same, they measure perceived enforcement with error.

\section{B. Stock-Market Effects}

How could antitrust have influenced stock prices? Many mechanisms are possible, but I will focus on three. One builds on Mitchell's analysis of the 1911 recession. The other two stem from the long debate on the monopoly problem and the rise of the modern corporation. Mitchell argued that trust prosecutions reduced orders in 1911 for new equipment in many industries.

Fresh alarm "was caused in October by the bringing of a federal suit against the United States Steel Corporation. Throughout the year, in fact, enterprise on the part of large capitalists was materially checked by

\footnotetext{
${ }^{63}$ The discovery and testimony in a federal case undoubtedly lowered the cost of a follow-up suit. Cases related to federal suits include Chattanooga Pipe and Foundry v. City of Atlanta 203 U.S. (1906) 390 (based on Addyston), International Harvester v. Missouri 233 U.S. 389 (1914), Minnesota v. Northern Securities 194 U.S. (1904), Harriman v. Northern Securities 197 U.S. 244 (1905). A purchaser from Corn Products claimed no obligation to pay for products bought from an antitrust violator: Wilder Manufacturing Co. v. Corn Products Refining Co. 236 U.S. 165 (1915). See also Buckeye Powder Co. v. DuPont Powder Co. 248 U.S. 55 (1918). In other cases, private action preceded the related federal suit. Hartman v. John D. Park and Sons 145 F. 358 (E.D. Ky. 1906) rev'd 153 F. 24 (6th. Cir. 1907), cert. dismissed 212 U.S. 588 (1908), stimulated the filing of U.S. v. National Association of Retail Druggists in May of 1906. These cases challenged the "direct contract" system of maintaining resale prices for drug wholesalers and retailers. See Joseph E. Fortenberry, A History of the Antitrust Law of Vertical Practices, 11 Res. L. \& Econ. 133 (1988).
} 
uncertainty regarding the legal position of business combinations. Hence all the trades that depend upon the volume of new construction put under contract found 1911 a dull year. Finance, of course, reflected this dullness in exaggerated fashion." 64

Let us take Mitchell's focus on uncertainty at face value but drop his view that the stock market overreacts. ${ }^{65} \mathrm{He}$ assumes no efficiency and no monopoly effects from merger, the holding company, and other disputed practices. Mere uncertainty causes stock prices to fall because business plans are on hold, and investment industries are especially hard hit. In the context here, federal lawsuits may be a proxy for uncertainty. Uncertainty aside, stocks of prospective defendants also should decline by the expected cost of defending the suit. Finally, defendants and potential defendants-all "trusts" and other news forms of business-also stood to lose organization-specific quasi rents, even if those firms were perfectly innocent of monopoly but not particularly efficient.

The uncertainty scenario begs a question: where did the trust and corporation problem come from? A spectrum of related "trust" forms arose in the late nineteenth century: the bona fide trusts, cartels, pools, holding companies, mergers, and interlocking directorates. It makes sense to view these as related devices, with the choice governed by the circumstances of a given industry, the changing technology of cooperative forms, and the volatile legal framework. By one time-honored hypothesis, the trusts were monopolies. ${ }^{66}$ Another venerated tradition emphasizes revolutions in transportation, production, distribution, and communication and the efficiency of the "visible hand" in some settings. ${ }^{67}$

Suppose textbook monopolies exist, and textbook antitrust cases are

${ }^{64}$ Mitchell, supra note 46 . Mitchell did not mention the trust question in his discussion of the 1907 panic, although the idea of a link was widespread at the time.

${ }^{65}$ Mitchell's invocation of "uncertainty" may simply have echoed the complaints by business leaders, found in note 45 supra.

${ }^{66}$ Thorelli, supra note 2. George J. Stigler, Monopoly and Oligopoly by Merger, $40 \mathrm{Am}$. Econ. Rev. (1950), reprinted in Stigler, The Organization of Industry (1968), examines the choice between two monopoly forms, cartel and merger.

${ }^{67}$ Alfred Chandler, The Visible Hand: The Managerial Revolution in American Business (1977). Turn-of-the-century economists often viewed cartels as a defense against cutthroat competition. More recent generations have dismissed the idea, but Telser's work on the core has put the notion of the infeasibility of competitive outcomes on firm theoretical footing. Lester G. Telser, Economic Theory and the Core (1978). Telser, supra note 2, gives an account of the rise of the trusts that emphasizes the obstacles that fixed costs place in the way of purely competitive outcomes. Naomi Lamoreux, The Great Merger Movement in American Capitalism, 1895-1904 (1985); and Bittlingmayer, supra note 6, also emphasize fixed costs in the search for cooperative forms at the turn of the century. 
then filed. The value of monopolies as well as the value of any free-riding competitive fringe should fall. The extent of the fall will depend on (1) the likelihood of a successful legal action, (2) the extent of monopoly rents at stake, and (3) the extent of monopoly in the economy since the suppression of widespread monopoly would increase aggregate demand, even for monopolies. ${ }^{68}$ Firms in competitive industries should be worth more, especially those buying from monopolies or selling to monopsonists. The effect on a broad stock index could be positive, negative, or zero, depending on the prevalence of monopoly among traded firms and in the economy as a whole.

Suppose instead that the trusts-broadly defined-promoted efficiency. A serious application of the Sherman Act would have eliminated the holding company and all merger activity. All firms that had made acquisitions during the merger wave of 1898-1902 were at risk. A finding of predation, for example, subjected firms to dismemberment. Arguably, the fate of the modern corporation was at stake.$^{69}$ Branded goods, patent licensing, and new methods of distribution were also under attack. Suppose these forms promoted efficiency. Filings should lower stock prices of defendants, likely defendants, and firms forced to change their business plans. Businesses that stood little chance of being sued would also suffer from an attack on efficient forms. ${ }^{70}$

These three mechanisms are not mutually exclusive. Antitrust enforcement may have made the legal status of corporations uncertain, it may have attacked classic monopolies, and it may may have attacked efficient forms of organization, all at the same time.

\section{The Data}

Table 2 lists the stock indexes used here and gives the number of firms in each index in January 1904 and July 1914 as well as the number of cases filed against firms in each index over that period. The Cowles series are value-weighted indexes based on all stocks traded on the New York

\footnotetext{
68 James M. Buchanan \& Dwight R. Lee, Private Interest Support for Efficiency Enhancing Antitrust Policies, 30 Econ. Inq. 218 (1992), relies on this point to generate a world in which organized private interests support the suppression of monopolies, including their own.

${ }^{69}$ Sklar, supra note 37, at 179: "The trust question was the corporation question. The great antitrust debates . . . were in essence, debates about the role and power of large corporations in the market and society at large."

${ }^{70} \mathrm{By}$ the available evidence, antitrust was directed at new efficient forms. See DiLorenzo, supra note 3; and Telser, supra note 2, at ch. 2.
} 
TABLE 2

Number of Stocks in Selected Indexes, 1904 and 1914, and Number of Cases Filed against Firms in Those Indexes, 1904-14

\begin{tabular}{lccc}
\hline \hline & \multicolumn{2}{c}{ Number OF Stocks IN INDEX } & \\
\cline { 2 - 3 } & January 1904 & July 1914 & $\begin{array}{c}\text { NumbER } \\
\text { OF CASES }\end{array}$ \\
\hline Cowles indexes: & 119 & 162 & \\
$\quad$ All-stock index & 62 & 103 & 24 \\
Industrials* & 45 & 44 & 12 \\
Railroads & 12 & 15 & 1 \\
Utilities & 8 & 9 & 0 \\
Miscellaneous services & 5 & 10 & 0 \\
Mining and smelting & 6 & 7 & 0 \\
Steel (without U.S. Steel) & 10 & 11 & 1 \\
Miscellaneous manufacturing & 12 & 12 & 4 \\
Dow indexes: & 20 & 20 & $8 \dagger$ \\
Industrials & & & 127 \\
Railroads & & & \\
$\quad$ Total cases filed, 1904-14 & & & \\
\hline
\end{tabular}

Note.-The 1913 American Telephone and Telegraph case was the one case against a Cowles utility, and the 1913 American Can case was the one case against a Cowles "miscellaneous manufacturing" firm.

* The Cowles "industrials" index includes all stocks except railroads and utilities.

†ncludes both Terminal Railroad cases (which involved multiple defendants), two cases each against the Reading and the New York, New Haven, and Hartford Railroads, and the filing against Union Pacific Coal.

$\ddagger$ Total cases filed excludes the three labor cases, one filed in 1908 and two in 1911, and it excludes U.S. v. One Hundred and Seventy-Five Cases of Cigarettes (1 D. \& J. 717), filed in 1907. Cases filed on the same day and involving the same industry or same defendants were counted as one case.

Stock Exchange (NYSE) ${ }^{71}$ Remarkably, many leading antitrust defendants are not part of the Cowles index before 1915. ${ }^{72}$

I use the Cowles all-stock index and its three components: industrials, railroads, and utilities. Of 127 cases filed, only twelve involved a Cowles industrial firm; eleven, a Cowles railroad; and one, a Cowles utility. In addition, I use those Cowles series with at least five stocks as of January

71 Alfred Cowles III and Associates, Common-Stock Indexes (1939). These series include all stocks traded on the New Stock Exchange and are based on the average of the monthly high and low, which induces some autocorrelation of returns. I use the series without dividends to facilitate comparison with the Dow, which also excludes dividends. The Dow indexes are end-of-month values from The Dow Jones Averages, 1885-1980 (Phyllis Pierce ed. 1982).

${ }^{72}$ Standard Oil, American Tobacco, and Otis Elevator were traded on the curb market in 1907. Other defendants from this era were not included in the Cowles series until much later: Kodak (1920), DuPont (1922), Cudahy Packing, Armour (1925), Aluminum Company of America, National Cash Register, Quaker Oats, Burroughs Adding Machine, and Swift (1926). 
1904 but no more than one case filing over the sample periodmiscellaneous services, mining and smelting, iron and steel (excluding U.S. Steel), and miscellaneous manufacturers. ${ }^{73}$ Stock-price movements in these indexes should reflect only the general effect of case filings for potential defendants, fringe firms, or firms facing no antitrust threat, not the threat to defendant firms. The data for the Dow indexes are also shown. All firms in the Dow were also in the Cowles index.

Notice that NYSE-listed railroads were actually more likely to be the target of a suit than NYSE industrial firms. This probably overstates the relative importance of antitrust for the railroad index. The handful of large, listed industrial defendants (U.S. Steel, International Harvester, American Sugar Refining, General Electric, Corn Products, American Can ranked $1,5,6,15,16$, and 19 , respectively, among the top fifty industrials in size of assets in 1908) and large, listed potential defendants probably figured heavily in the value-weighted industrial index. Railroads also came under a different although related regulatory regime with the Hepburn Act of 1906 (not to be confused with the 1908 Hepburn Bill) and the Mann-Elkins Act of 1910. The iron and steel series, which excludes U.S. Steel, provides a particular illustration of how actual enforcement was a poor proxy for the likely threat from Justice Department lawyers. No firm in that index was sued, but the Sherman Act was ripe with potential. Bethlehem Steel, Republic Steel, and U.S. Pipe and Foundry (the Addyston defendants), for example, were all the products of merger.

\section{The Dow-Jones Industrial Average and Antitrust Case} Filings, Results Based on Six- and Twelve-Day Periods

This section presents some estimates of the short-run effects of antitrust enforcement. The two variables are the case filings and the return on the Dow industrial average over six- and twelve-trading-day periods. I use the Dow because it is available on a daily basis. Of the twelve stocks in the index at any one time, four were involved in federal antitrust suits before 1914-U.S. Steel common and preferred, American Sugar common, and General Electric common. These constitute roughly 3 percent of all case filings for this period. Since stocks were traded on Saturdays until the late 1940s, six and twelve days correspond roughly to one and two weeks.

\footnotetext{
${ }^{73}$ Although railroad equipment should be included under this criterion, I left it out because it seemed likely to be heavily influenced by the fate of the railroads. Mitchell, supra note 46 , at 85 , reports that the February 1911 ICC refusal to allow railroad-rate increases reduced orders for equipment.
} 
My aim is to see whether case filings lowered the Dow over short time periods. Since it takes at least several weeks to prepare an antitrust case, a finding of a significant short-term association would tip the balance in favor of finding that antitrust filings cause stock-price changes rather than the other way around. The estimated effect per case over this short period is also of interest. Since estimated coefficients from longer periods are clouded by the suspicion of endogeneity - past stock-price declines causing case filings - the short-term results are a skeptic's estimate of the effects of case filings.

Let $\operatorname{DOW}(t, t-k) k=6,12$, be the return on the Dow from the end of day $t-k$ through the end of day $t$, and let $\operatorname{CAS}(t, t-k), k=6,12$, equal the number of cases filed from the end of day $t-k$ through the end of day $t$. Consider a formulation in the spirit of Granger "causality" or temporal association: do past returns and case filings predict current returns? The estimated model for six-day periods is specified as

$$
\begin{aligned}
\operatorname{DOW}(t, t-6)= & a+b_{0} \operatorname{DOW}(t-6, t-12) \\
& +\sum_{i=1}^{T} b_{i} \operatorname{CAS}(t-6 i, t-6(i+1))+v_{t, t-6}-6,
\end{aligned}
$$

with $T=3$ and 6 . Regressions for twelve-day periods are defined analogously. Only one lag of Dow returns is included because of the wellknown result that stock returns follow a near-random walk. The one lag here merely confirms that fact. Can we, however, reject the hypothesis that the $b_{i}$ are jointly equal to zero?

My estimates and exclusion tests for (1) appear in Table 3. I also include current case filings in an alternate specification. Neither past returns nor past case filings influence current returns, but the coefficient on CAS $(t, t-6)$ (concurrent returns) indicates that a case depresses DOW in the same six-day period by $.423(t=2.27)$ to .444 percent $(t=$ 2.37). The rejection of the null hypothesis for lagged effects would be surprising since it would imply that an observable variable Granger causes stock returns. The estimated effect over concurrent twelve-day periods is slightly lower and has a substantially higher standard error.

If case filings are anticipated on average, a different approach is in order. The top set of results in Table 4 show regressions of six- and twelve-day Dow returns on the number of cases over leading periods (end of day $t$ to end of day $t+24$ ) and over the lagging/concurrent periods (end of day $t-24$ through the end of day $t$ ). ${ }^{74}$ These results

\footnotetext{
${ }^{74}$ On the use of explanatory variables defined over periods greater than the sampling interval, see Robert J. Hoderick, Dividend Yields and Expected Stock Returns: Alternative
} 
TABLE 3

Regressions of Six- and Twelve-Day Returns on Lagged Returns and Lagged Case FILINGS, JanUARY 1904-JULY 1914

\begin{tabular}{|c|c|c|c|c|c|c|c|c|}
\hline & \multicolumn{2}{|c|}{ (1) } & \multicolumn{2}{|c|}{ (2) } & \multicolumn{2}{|c|}{ (3) } & \multicolumn{2}{|c|}{ (4) } \\
\hline & $b_{i}$ & $\mathrm{SE}\left(b_{i}\right)$ & $b_{i}$ & $\operatorname{SE}\left(b_{i}\right)$ & $b_{i}$ & $\mathrm{SE}\left(b_{i}\right)$ & $b_{i}$ & $\overline{\mathrm{SE}\left(b_{i}\right)}$ \\
\hline \multicolumn{9}{|l|}{$\begin{array}{l}\text { A. Six-day returns: } \\
\operatorname{DOW}(t, t-6) \text { : }\end{array}$} \\
\hline Constant & .45 & .12 & 1.11 & 1.27 & .33 & .14 & 1.04 & 1.41 \\
\hline $\operatorname{DOW}(t-6, t-12)$ & .03 & .04 & .02 & .04 & .03 & .04 & .02 & .04 \\
\hline $\operatorname{CAS}(t, t-6)$ & & & -4.23 & 1.86 & & & -4.44 & 1.87 \\
\hline $\operatorname{CAS}(t-6, t-12)$ & -.08 & 1.86 & .14 & 1.86 & .07 & 1.88 & .32 & 1.87 \\
\hline $\operatorname{CAS}(t-12, t-18)$ & -.97 & 1.82 & -.19 & 1.85 & -.61 & 1.88 & .26 & 1.90 \\
\hline $\mathrm{CAS}(t-18, t-24)$ & 3.08 & 1.85 & 3.54 & 1.85 & 3.28 & 1.90 & 3.82 & 1.91 \\
\hline $\operatorname{CAS}(t-24, t-30)$ & $\ldots$ & & & & -1.43 & 1.92 & -1.64 & 1.92 \\
\hline $\operatorname{CAS}(t-30, t-36)$ & $\ldots$ & & & & -1.13 & 1.91 & -1.28 & 1.90 \\
\hline $\mathrm{CAS}(t-36, t-42)$ & $\ldots$ & & & & .66 & 1.87 & .53 & 1.87 \\
\hline $\operatorname{CAS}(t-42, t-48)$ & $\cdots$ & & & & 1.68 & 1.87 & 2.00 & 1.87 \\
\hline$R^{2}$ & .01 & & .02 & & .01 & & .02 & \\
\hline Exclusion test* ${ }^{*}$ & .39 & & .09 & & .72 & & .26 & \\
\hline \multicolumn{9}{|l|}{$\begin{array}{l}\text { B. Twelve-day returns: } \\
\text { DOW }(t, t-12) \text { : }\end{array}$} \\
\hline Constant & 1.90 & 2.44 & 3.20 & .26 & 1.39 & 2.74 & 2.67 & .29 \\
\hline $\operatorname{DOW}(t-12, t-24)$ & .04 & .06 & .02 & .06 & .04 & .06 & .02 & .06 \\
\hline $\operatorname{CAS}(t, t-12)$ & & & -3.67 & 2.50 & $\ldots$ & & -3.64 & 2.52 \\
\hline $\operatorname{CAS}(t-12, t-24)$ & .25 & 2.40 & 1.22 & 2.48 & -.08 & 2.51 & .96 & 2.60 \\
\hline $\operatorname{CAS}(t-24, t-36)$ & $\ldots$ & & . & & 1.15 & 2.60 & .86 & 2.60 \\
\hline $\operatorname{CAS}(t-36, t-48)$ & $\ldots$ & & & & .28 & 2.50 & .51 & .25 \\
\hline$R^{2}$ & .00 & & .01 & & .00 & & .01 & \\
\hline Exclusion test* & .92 & & .34 & & .97 & & .67 & \\
\hline
\end{tabular}

NotE.-Coefficients and standard errors for the constant and for the CAS variables have been multipled by 1,000. Consequently, the CAS coefficients give the per-case effect in tenths of a percent. DurbinWatson statistics for these regressions fell in the range $[1.97,2.00]$ and the Ljung-Box test indicated no general serial correlation of the error term. Estimates for six-day case filings are based on 520 observations; those for twelve-day filings on 260.

* Significance level of the $F$-test for the hypothesis that the coefficients of the CAS variables are zero.

show dramatically that future cases are associated with negative current returns. Current and past cases have little if any influence. The results in the lower half of Table 4 show that this also holds if cases from the next forty-eight days are used, but the estimated standard errors are larger. The per-case effect can be obtained by multiplying the estimated coefficient by the number of sample intervals in twenty-four or forty-eight days. For six-day returns, each case filed results in a .732 percent decline in the Dow over the period $t+24$ to $t-24$. The coefficients measure

Procedures for Inference and Measurement (unpublished manuscript, Kellog Graduate School Mgmt., Northwestern Univ., June 4, 1990). 
TABLE 4

Regressions of Six- and Twelve-Day Returns on Case Filings Summed over Leading and Lagging Periods Longer than the Sampling Interval, January 1904-July 1914

\begin{tabular}{|c|c|c|c|c|}
\hline & \multicolumn{2}{|c|}{$\begin{array}{l}\text { 6-DAy RetURnS: } \\
\text { DOW }(t, t-6)\end{array}$} & \multicolumn{2}{|c|}{$\begin{array}{l}\text { 12-DAy ReTURNS: } \\
\text { DOW }(t, t-12)\end{array}$} \\
\hline & $b_{i}$ & $\operatorname{SE}\left(b_{i}\right)$ & $b_{i}$ & $\operatorname{SE}\left(b_{i}\right)$ \\
\hline Constant & 2.68 & 1.40 & 6.07 & 2.82 \\
\hline $\mathrm{CAS}(t+24, t)$ & -1.97 & .77 & -3.36 & 1.49 \\
\hline $\mathrm{CAS}(t, t-24)$ & .14 & .77 & -.86 & 1.49 \\
\hline$R^{2}$ & .01 & & .02 & \\
\hline$D-W$ & 1.95 & & 1.97 & \\
\hline Constant & 2.78 & 1.57 & 5.99 & 3.16 \\
\hline $\mathrm{CAS}(t+48, t)$ & -1.29 & .51 & -2.41 & 1.02 \\
\hline $\mathrm{CAS}(t, t-48)$ & .34 & .51 & .37 & 1.01 \\
\hline$R^{2}$ & .01 & & .02 & \\
\hline D-W & 1.96 & & 1.96 & \\
\hline
\end{tabular}

NOTE.-Coefficients and standard errors have been multiplied by 1,000. Consequently, the coefficients show in tenths of a percent the effect on stock prices in a given six- or twelve-day period per case filed over twenty-four or forty-eight days.

the decline in tenths of a percent, hence in tenths, we have $7.32=(-1.97$ $+.14) \times 4$.

\section{Monthly Stock Prices, Industrial Production, and Case Filings}

I now turn to an examination of monthly data, which allows me to look at a variety of Cowles indexes and not just the Dow. Moreover, the Babson index of industrial production is also available monthly, giving me an explanatory variable that reflects factors not reflected by case filings. ${ }^{75}$ Finally, monthly data permit fairly parsimonious estimates of the effects over horizons extending several months.

I will now change notation slightly, partly to emphasize that I am dealing with different data. Define the following variables:

$$
\begin{aligned}
\mathrm{RET}_{t}= & \text { percentage change in one of the stock indexes in Table } 2 \\
& \text { from month } t-1 \text { to month } t, \\
\mathrm{CAS}_{t}= & \text { number of federal antitrust cases filed in month } t .
\end{aligned}
$$

75 The Babson index is from 2 Bus. Cycle Indicators 130, table 15.1 (Geoffrey H. Moore ed. 1961). It is based on physical production in manufactures, mining, agriculture, construction, railroad transportation, electricity generation, and foreign trade, with the weights based on value added. 


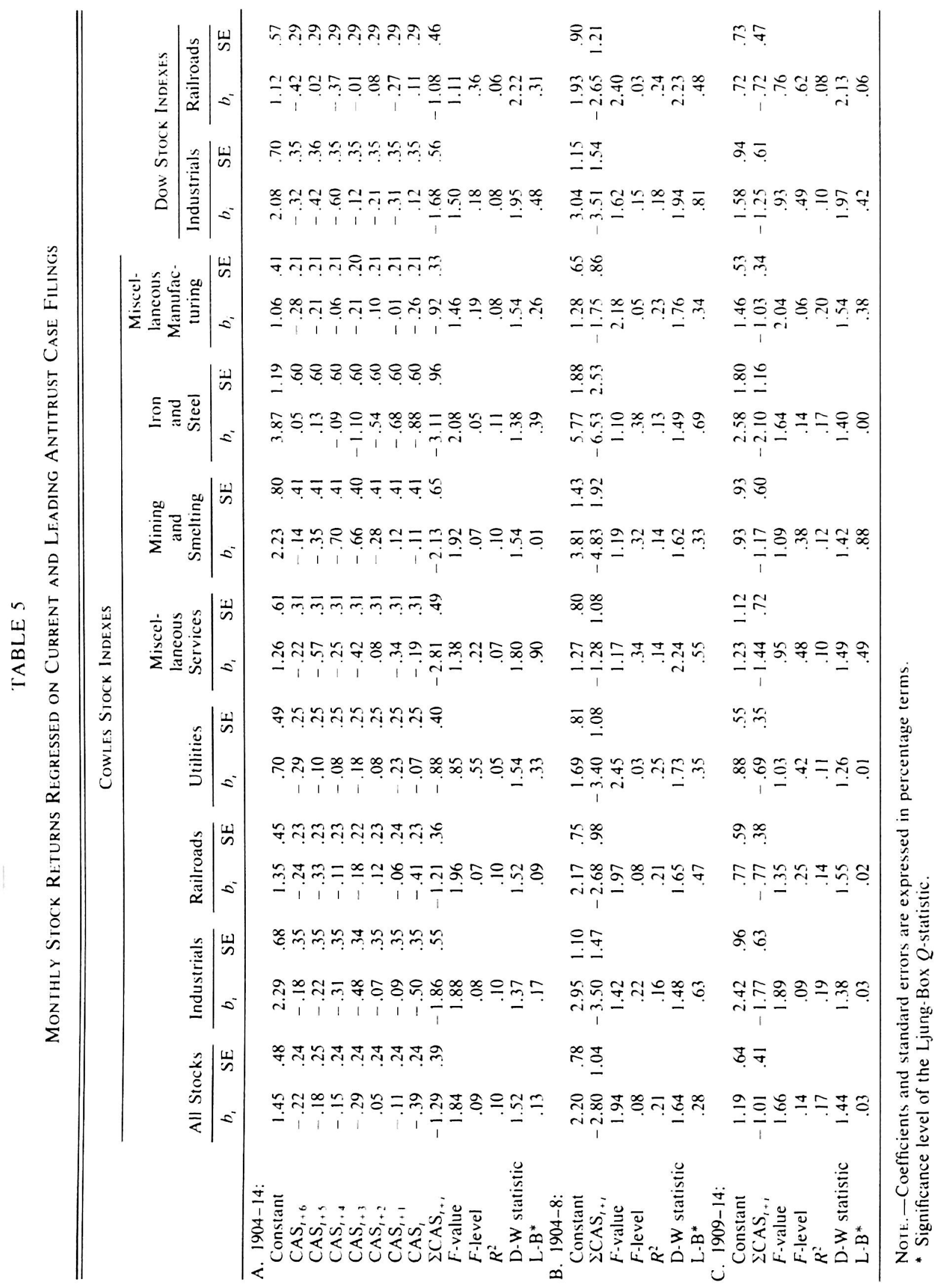


My regressions in Table 5 follow the form

$$
\operatorname{RET}_{t}=a+\sum_{i=0}^{T} b_{i} \mathrm{CAS}_{t+i}+e_{t},
$$

with $T=6$ for the ten different stock price indexes. Broadly speaking, each case per month is associated with a 1-3 percent decline of the various indexes. This decline is more pronounced in 1904-8, where the all stock index drops 2.80 percent and runs between 1.75 percent (miscellaneous manufacturing) and 6.53 (steel excluding U.S. Steel). It falls somewhat for 1909-14 to 1.01 for the all-stock index and runs between .69 (utilities) and 2.10 (steel excluding U.S. Steel). Note that, for 1904-14 as a whole, thirty-seven out of forty coefficients for leads 3-6 are negative, but only two-thirds (twenty-one out of thirty coefficients) are negative for leads $0-2$. Finally, all cumulative coefficients are negative.

Consider the industry effects. Although only one case was filed against the firms in the four industrial indexes (miscellaneous service, mining and smelting, iron and steel, and miscellaneous manufacturing), each experienced declines of .92-6.53 percent per case, depending on the industry and period. These cumulative coefficients are typically two to three times as large as the estimated standard error. The utilities also declined sharply in 1904-8, although the only utility suit was filed in 1913. Both results support the idea that the actual pattern of enforcement provides only a rough guide to the particular firms and industries at risk. The strong negative effects for iron and steel supports either the idea that the fringe steel firms benefited from the U.S. Steel's high prices or that they were also likely targets of attack. The consistent negative effects in the two diversified groups (miscellaneous services and miscellaneous manufacturing), however, seems to suggest that these firms were themselves likely targets. The decline in railroads was about two-thirds as large as the decline in industrials for 1904-8 but only half as great for 1909-14, which is consistent with the declining importance of antitrust for railroads.

The relation of the $t$-statistics for the sums of the case coefficients and the $F$-statistics for the hypothesis that the coefficients are jointly equal to zero deserves comment. Figure 2 provides the $t$ - and $F$-statistics for equation (2) using the Cowles all-industry return with values of $T=$ $0, \ldots, 8$. Clearly, the $t$-statistic rejects the hypothesis of zero effects for long and short distributed leads. The $F$-statistic falls off rapidly, however, and rejects the null decisively only for the first few values of $T$. My inclination has been to set $T=6$ because the historical and institutional evidence suggests leakages as far as six months in advance of a case filing and because the inherent errors-in-variables problem is mitigated by looking over longer periods. 


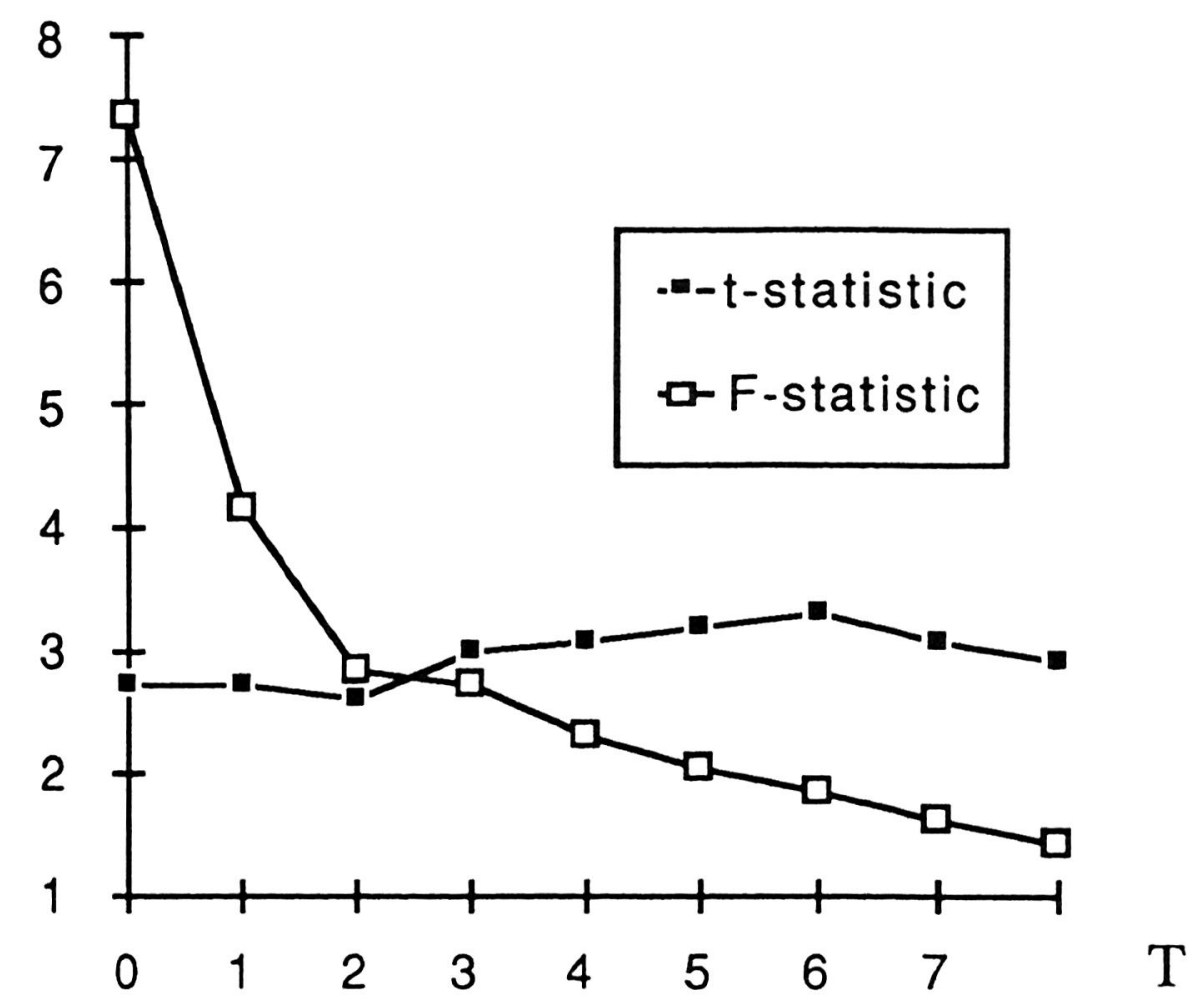

FIGURE. 2.-F- and $t$-statistics for $\mathrm{RET}_{t}=a+\sum_{i=0}^{T} b_{i} \mathrm{CAS}_{t+i}+e_{t}, T=0, \ldots, 8$, with $\mathrm{RET}_{t}$, based on the all-industry Cowles index.

The estimates in Table 5 are not driven by the cases filed against firms in the index. I get nearly identical results when I use only cases against firms not in the Cowles index. They are also not driven by spikes in the case filings series. Unreported regressions using a dummy variable based on $\mathrm{CAS}_{t}>0$ yield essentially similar results. Table 5 results are also not driven by the Panic of 1907 , although that year was different. A binary variable equal to one for January-December 1907 yields a coefficient of -4.13 percent $(\mathrm{SE}=.89$ percent) and a summed case effect of -1.36 percent $(\mathrm{SE}=.36$ percent) for the all-industry Cowles regression. Regressions based on the other indexes provide similar results. Estimates restricted to 1904-8 yield a coefficient of -4.29 percent for the 1907 months, per-case effects roughly half as large as in the middle panel of Table 5, and slightly lower standard errors.

What was special about 1907? Aspects of antitrust not reflected in filings data provide some possible answers. The government pursued Standard Oil aggressively for most of the year, it raised the possibility of criminal charges, it sought to put antitrust defendants in receivership, Roosevelt worked the trust question politically, and at least one major case was planned and then abandoned. Traditional accounts of the Panic 
of 1907 emphasize troubles in the banking sector, but those troubles occurred in October and November, well after most of the stock decline. Bank panics may themselves be symptoms rather than causes.

A further test of the robustness can be obtained by including current and future values of industrial production. ${ }^{76}$ Table 6 has regressions of the form

$$
\mathrm{RET}_{t}=a+\sum_{i=1}^{6} b_{i} \mathrm{CAS}_{t-i}+\sum_{i=1}^{6} c_{i} \mathrm{CHPRD}_{t-i}+e_{t},
$$

where $\mathrm{CHPRD}_{t}$ is the percentage change in Babson's industrial production series. This specification is an atheoretical way of controlling for other factors that may influence stock prices. These other factors, distilled in measured production, may be conventional monetary and fiscal policy, or they may be other varieties of business policy, including the struggle over the trust question.

The summed coefficients for industrial production typically take on values of one to two, with higher values prevalent for cyclical stocks (industrials, mining and smelting, and iron and steel). These estimates are consistent with results from previous studies, which regard stock prices as reflecting levels of expected future production. ${ }^{77} \mathrm{~A} 1$ percent decline in industrial production lowers stock prices about 1 percent. The cumulative case filing coefficients are still uniformly negative and statistically significant in most instances. Note, however, that they are smaller for 1904-8 than in Table 5 but not for 1909-14. Consequently, the cumulative effects are still two to three times as large as the estimated standard errors for the period as a whole and for 1909-14 but not for 1904-8. The $F$-statistics for the hypothesis that the joint effect of the case variables is zero drop slightly for railroads and utilities in 1904-8 and drop substantially for industrials. They increase somewhat for 1909-14, however. The significance levels often fall short of conventional standards, but this is largely a consequence of the number of leads used. I could have generated higher $F$-statistics by a judicious choice of leads.

Tables 5 and 6 show uniformly negative effects of filings on stock prices of individual industries. This holds for various specifications, for industries with no antitrust defendants, and for both subperiods. The absence

\footnotetext{
76 The use of future values of industrial production to explain stock-price variation is defended in Eugene F. Fama, Stock Returns, Expected Returns and Real Activity, 45 J. Fin. 1089 (1990); and G. William Schwert, Stock Returns and Real Activity: A Century of Evidence, 45 J. Fin. 1237 (1990).

${ }^{77}$ Fama, supra note 76; and Schwert, supra note 76.
} 


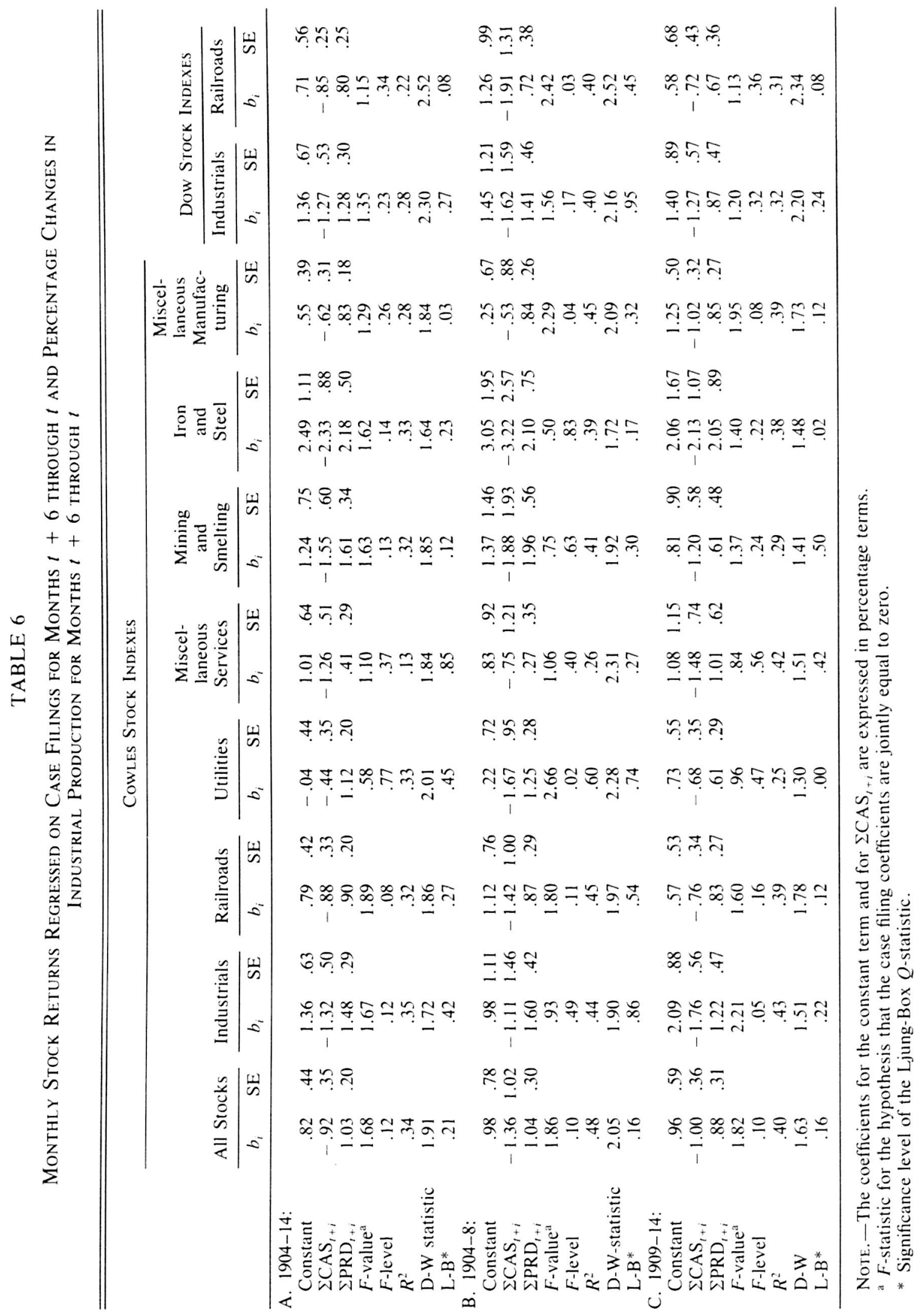


of positive industry effects supports Mitchell's uncertainty mechanism, it supports the hypothesis that publicly traded firms were typically monopolies, and it supports the view that the target corporations promoted efficiency. It fails to support the view that antitrust created winners as well as losers among identifiable groups of publicly traded firms by, say, eliminating efficiency-reducing monopolies. ${ }^{78}$

The long-term effects of antitrust on stock prices are also of interest, but a reliable estimate would require long-term data. Some back-of-theenvelope calculations are instructive. Compare August 1901, that is, just before McKinley's assassination and after five years of unprecedented expansion, with August 1909, when it seemed that the Republicans had accommodated themselves to scaled-back enforcement and compromise on the trust question. Only two cases were filed between June 1908 and December 1909. ${ }^{79}$ The Dow Industrials (excluding dividends) increased at 4.2 percent per year over those eight years, and the Cowles industrial index (including dividends) increased at 12.0 percent. This is one guess of the net effects of a regime of steady, scaled-back enforcement. Of course, the antitrust genie was not entirely back in the bottle in 1909, and the Panic of 1907 may have had some lasting repercussions.

Conversely, stock prices over the period 1909-14, during the Taft and early Wilson administrations, provide the best guess of the effects of a sustained shift to vigorous enforcement. I will use the June values for both 1909 and 1914 to avoid any contamination by the July-August 1914 political crisis in Europe. The Dow dropped 2.5 percent per year, the Cowles increased by 5.3 percent per year. The net decrease in the rate of growth from 1901-9 to 1909-14 was 6.7 percentage points for both stock indexes. So, that drop represents a tentative estimate of the net effect of a permanent shift in antitrust regimes on the level of stock prices. They were $33.5(=6.7 \times 5)$ percent lower.

\section{Antitrust's Effects on the Stock Prices of Defendant Firms}

This section looks at effects of antitrust case filings on the stock prices of individual defendant firms. If the stock prices of actual targets of fed-

\footnotetext{
${ }^{78}$ Should not the case-filings variable be unexpected case filings? In principle, yes. But the construction of a measure of unexpected filings typically involves subracting an average of past filings from current filings. In 1904-14, antitrust was new and shifted quickly, so that subtracting an average of past filings-say the predicted value of an autoregressionleaves the results largely unaffected or merely adds noise. In work covering later years, this strategy yields the expected results. George Bittlingmayer, Stock Returns, Real Activity and the Trust Question, 47 J. Fin. 1701 (1992).

79 The two were Allen Bros. (April 1909) and American Sugar Refining (July 1909).
} 
eral actions dropped substantially more than the Dow, then the Dow's drop of 1-3 percent per case can be rationalized at least in part as the market's response to a higher perceived probability of future filings against individual firms. An event study can also throw light on the question of whether filings were exogenous. If the stock prices of individual targets dropped at the same time as the Dow, roughly over the six months preceding a filing, then we have circumstantial evidence that the Dow's drop took place in anticipation of increased filings. ${ }^{80}$

Of the firms sued by the government between January 1904 and July 1914, eleven had stock traded continuously and reported in the Wall Street Journal from three years before the filing until one year after. Of these, eight also had traded preferred stock. Four stocks in the Dowthree common and one preferred-belonged to the eleven target firms, but this only biases the results against finding any firm-level effect. Table 7 presents the results of a conventional event study in which the month of the filing is defined as month [0]. I use the Dow rather than the Cowles index because the Cowles is based on averages of monthly highs and lows rather than end-of-month values.

Unusually large negative residual returns are clustered in months [ -4 , 1]. The cumulative decline over those months for the common and preferred stocks taken together is -9.34 percent. Common and preferred both drop roughly 10 percent over the year leading to the case filing, but common drops 11.32 and preferred 6.62 percent over months $[-4,1]$. The common stock of defendant firms also continues to decline more sharply after the filing, dropping another 11.1 percent over $[1,12]$, as compared to 2.02 percent for the preferred. ${ }^{81}$ The fraction of positive residual returns is also particularly low in the months leading up to a filing. These results provide strong evidence that antitrust cases were anticipated over a period of several months on average, which is consistent with the historical accounts for individual cases. They also yield per-firm effects nearly an order of magnitude greater than for the all-stock Cowles index.

\footnotetext{
${ }^{80}$ These results are also of independent interest. Burns, supra note 22 , at 717 , found that three antitrust suits filed in 1906 and 1907-snuff, tobacco, and oil-lowered common stock prices 6.3-16.1 percent in the months $[0,1]$. My results are based on a broader sample that includes many filings after the Panic of 1907.

${ }^{81}$ Part of this difference is no doubt due to Standard Oil, which did not have traded preferred. The calculated beta for Standard is low, .10 for months [ $-35,-12]$ and .31 for $[-35,+12]$, possibly reflecting the special factors influencing Standard's fortunes. As a result, Standard's decline over November 1905-November 1907 of 41 percent is attributed largely to idiosyncratic rather than "market" factors. Standard's "idiosyncratic" drop of 11 percent in November 1907, a year after the filing, also contributes substantially to the large negative return for month [12] in the results.
} 


\section{Concluding Comments}

Franklin Fisher faults the Handbook of Industrial Organization for its neglect of antitrust policy. Indeed, he argued that recent theory provides little if any illumination in actual cases. ${ }^{82}$ But I think we can go further. Industrial economics should take its cue from monetary economics, where speculation about policy is informed by knowledge of monetary institutions and estimates of the effects of policy in the past. We should know as much about antitrust under Roosevelt, Taft, and Thurman Arnold (Franklin Roosevelt's antitrust chief) as monetary economists know about free silver or Federal Reserve policy in the 1930s.

I have looked at the stock-market reaction to antitrust case filings during the trust-busting era. Broad indexes declined 1-3 percent in advance of filings, and industry indexes with no antitrust filings declined as much as 10 percent. The basic result holds for two subperiods, 1904-8 and 1909-14, and it holds using future industrial production as an extra explanatory variable. The common and preferred stocks of firms actually filed against declined substantially more than the Dow in the months leading up to the filing. Three explanatory mechanisms are possible.

If we go with Mitchell and emphasize uncertainty, trust-busting may have had no effect on efficiency in the long run but reduced production and investment over the short run and hence stock prices. Quasi rents to existing organizations also fell. But this story is incomplete: it offers no reason for the rise of the trusts and corporations in the first place. It seems unlikely that serendipity created Standard Oil and U.S. Steel.

The long debate on monopoly and the modern corporation offers two other mechanisms. Stock prices would fall in a world where (1) monopoly was widespread among publicly traded firms and (2) the antitrust authorities could reliably detect and eliminate monopoly without causing much collateral damage. But other implications of that sort of triumph of good over evil are not borne out. By the available evidence, early trust-busting was typically directed at new, fast-growing industries, and the ability of the Sherman Act reliably to detect and fix efficiency-reducing monopoly remains undemonstrated to the present day.

Finally, these results could have been generated if antitrust largely missed the textbook monopolies and if efficiency rationales were the

${ }^{82}$ Franklin M. Fisher, Organizing Industrial Organization: Reflections on the Handbook of Industrial Organization, Brookings Papers Econ. Activity: Microeconomics 205, 220 (1991). In fact, the volume covering empirical and policy issues has no index entry for "antitrust." 2 Handbook of Industrial Organization (Richard Schmalensee and Robert Willig, eds. 1989). Ironically, one of the editors served as chief economist of the Antitrust Division from 1989 to 1991. 


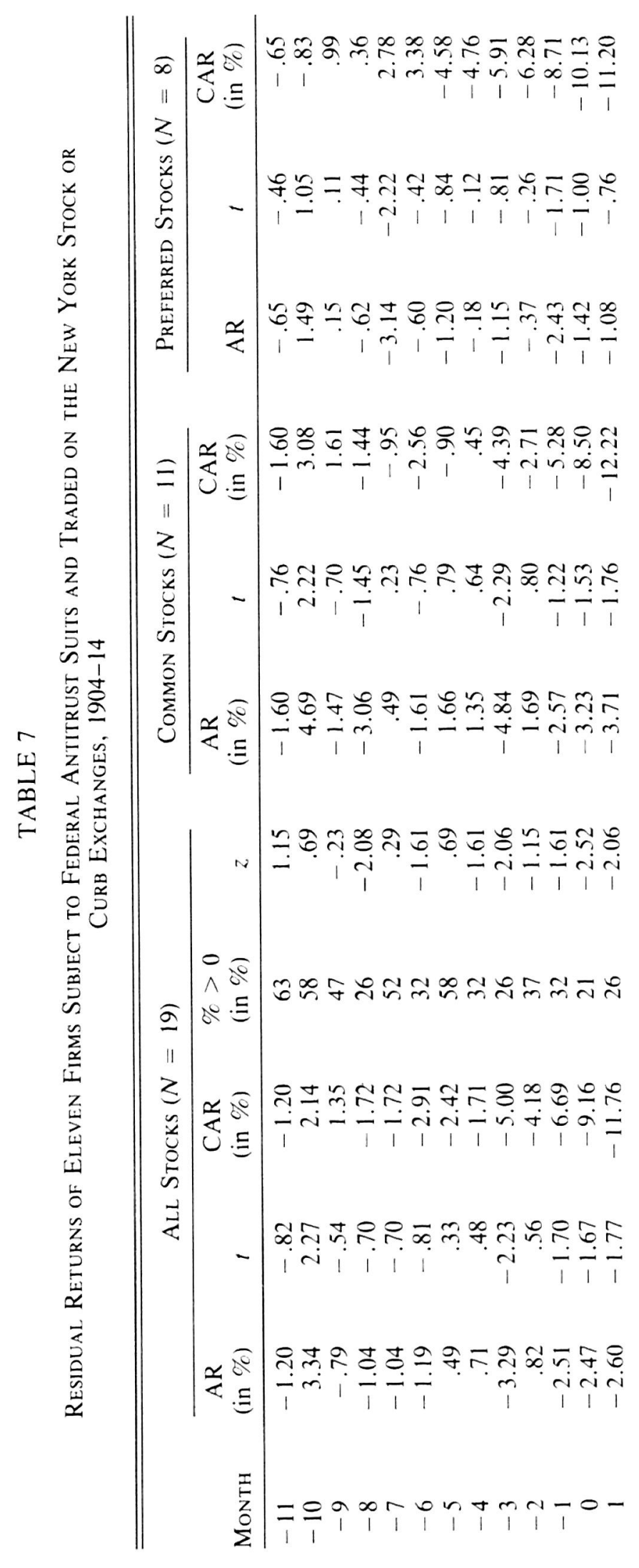




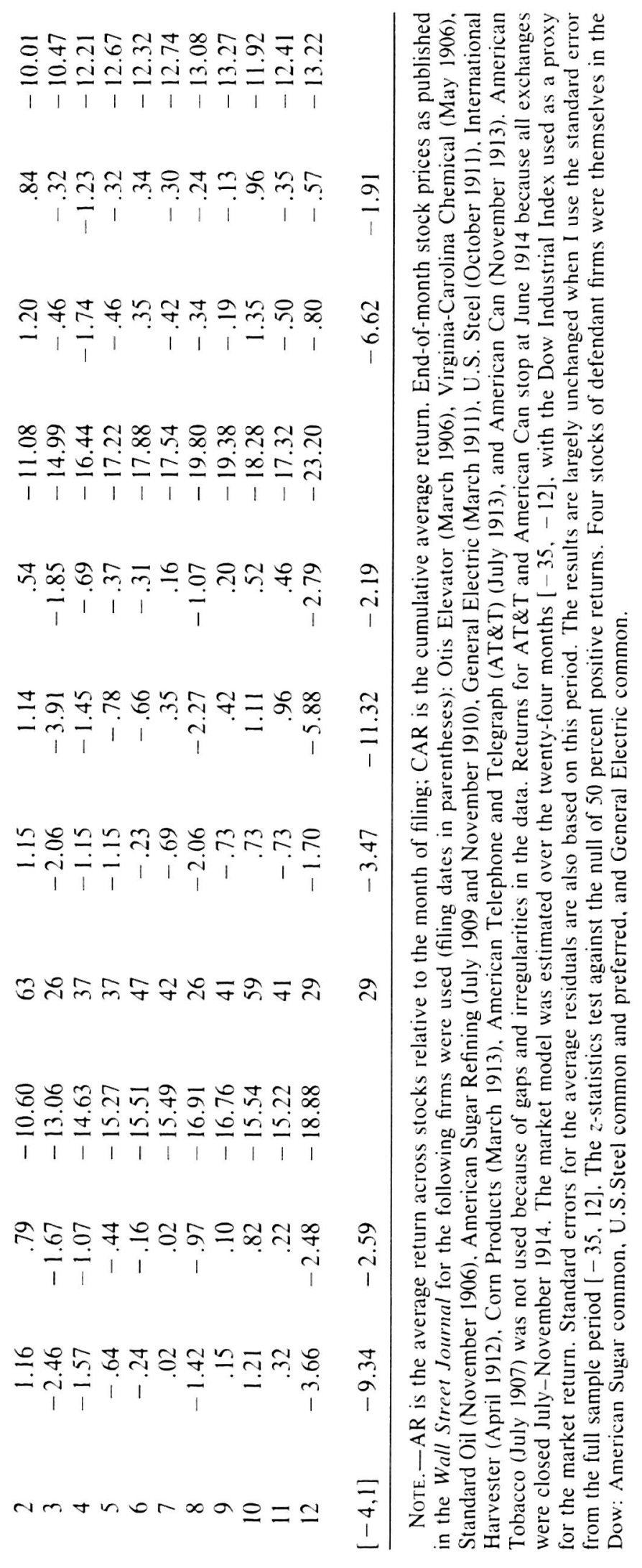


dominant motive for the disputed practices. All three mechanisms could have been at work in individual cases, but the last one leaves fewer stray ends.

Future work can go in several directions. First, since actual filings capture only a fraction of the turmoil surrounding the trust and corporation problems during antitrust's classic era, other actions by the president, Congress, the courts, private parties, and states may explain some stock movements, particularly during the Panic of 1907. Second, other periods and related policies are worth studying. The trust question was not settled in 1914. It emerged as an issue again and again-during Wilson's second term, during Herbert Hoover's and Franklin Delano Roosevelt's administrations, as well as during Lyndon Johnson's and Richard Nixon's presidencies. ${ }^{83}$ Third, it might be possible to obtain independent measures of the degree of monopolization and efficiency by industry and relate these to the stock-price declines. That strategy is likely to have a higher payoff with periods more recent than the turn of the century because the industry data are better and because many more firms have quoted stock prices.

${ }^{83}$ In a related article, Bittlingmayer, supra note 78 , I look at qua 1 erly returns for the period 1904-45, in particular the policy reversal under Hoover announced on Friday, October 25, 1929, and the aggressive regime of enforcement under Thurman Arnold in the late 1930s. 